\title{
Developing Smart Based Ethernet Remote Monitoring Model for PV System
}

\author{
Omorogiuwa Eseosa*, Dike Ifeanyichukwu Chukwudi \\ Electrical/Electronic Engineering, Faculty of Engineering, University of Port Harcourt, Rivers State, Nigeria
}

DOI: $\underline{10.36348 / \text { sjet.2020.v05i02.001 }}$ | Received: 14.01 .2020 | Accepted: 22.01 .2020 | Published: 14.02 .2020

*Corresponding author: Omorogiuwa Eseosa

\section{Abstract}

The challenges of unmonitored or partial usage of solar power for cooperate firms that generate this power has motivated the need for this research to develop a smart system to monitor and control the varying parameters of PV systems. Voltage, current and temperature sensors were used to monitor the energy generated, consumed, stored and losses that are connected to the system. This system was able to monitor radiations from the sun and temperatures of the PV modules. Also, with the aid of programmable microcontrollers, ECUs and routers, gathered information was transmitted real-time for a specified period. Results were displayed in digital values using graphs and. transmitted to the internet with aid of dedicated servers. This system senses slightest variations on variables, captures any anomaly and transmits prompt results via text message / internet. It is recommended that microchips' Internet of Things (IOT) board should be utilized in future monitoring due to its shorter deployment time and encrypted transmission of data. Moreso, cooperate bodies and individuals investing on PV systems in terms of security should be supported fully most especially by the government and renewable energy policies as practiced in developed nations should be emulated by developing and underdeveloped nations.

Keywords: IOT, ETHERNET, PV, ECU, RMS.

Copyright @ 2020: This is an open-access article distributed under the terms of the Creative Commons Attribution license which permits unrestricted use, distribution, and reproduction in any medium for non-commercial use (NonCommercial, or CC-BY-NC) provided the original author and source are credited.

\section{INTRODUCTION}

In insurance backed PV system, the insurance provider monitors the use of the system remotely so as to eliminate or reduce false insurance claims. PV systems are self-sustaining ideally. A PV system is designed to convert light energy to electricity through the use of PV modules. It is usually integrated with batteries and inverter for stability and continuous power supply. PV systems are known to require low operating expenditure (OPEX) when used properly and a high initial capital expenditure (CAPEX). This high CAPEX is a factor militating against rapid deployment of PV system especially in developing countries or areas without government support for PV system. To tackle this issue, private financiers or developers are pushing for PV system deployment with comprehensive insurance. The comprehensive insurance will ensure that their investment will not go down the drain if there is any failure. To ensure that the PV systems are run based on the recommended framework and hence ensure its sustainability while reducing risk exposure of insurer/insurance companies, the need for remote monitoring system (RMS) arises. This external system known as RMS monitors the power generated by each
PV module, detect malfunctioning PV modules, detect intrusion, and take note of inverter load. RMS serves as an interface between PV system and insurance cover provider, and its main object is the correct usage of the system so as to reduce unnecessary insurance claims and also forewarn the PV system operator or end user. During operation, the RMS monitors status of PV modules, inverter output and batteries depth of discharge. RMS helps in ensuring the viability of the PV system and insurance providers. It should be noted that unmonitored usage of remote PV system installation leads to downtime and sudden failure of the PV system. It also exposes the insurer to blind payment of insurance claims. A typical end user will deny using the PV system improperly when there is system failure. If the insurance provider pays for all the insurance claims without verifying them, they will run into losses and may collapse thereby leading to lose of investors' money altogether. The insurer will also not be able to pay claims to other clients that took up comprehensive insurance for their PV system even if there is genuine claim. PV system financiers are also weary of putting down their money if there is no or poor performance monitoring of their investment. An economic loss due 
to downtime also arises from not detecting and replacing a malfunctioning component of the PV system. This paper aim to design Smart Remote System for Monitoring PV System. Specifically, the objectives include

- Design RMS that will estimate inverter load and send out warning if loaded above $70 \%$ of its capacity.

- Design RMS that will show individual power generated by PV modules and detects its malfunctioning, intrusion or theft.

- Design RMS that estimates the batteries voltage.

- Design RMS that communicates over the web in real time.

\section{REVIEW OF RELATED WORKS}

Photo Voltaic (PV) system is gaining general acceptance and success around the globe though usually supported by government policies. A PV system is a power system designed to supply solar power by means of converting light incident on a semiconductor material to electricity. The material is generally known as solar panel and this phenomenon is called photo voltaic effect. Photo voltaic effect is the producing of current and (or) voltage when light of appropriate wavelength/frequency falls on a solar panel (or any other photo voltaic material). Photo voltaic effect is closely related to photo electric effect, but the distinction is that current ejected out of the material while in that of photo voltaic effect, the current remains within the material. A PV system is usually integrated with charge controller, inverter and deep cycle battery to convert the generated electricity to a useable form and for stability. Solar system is a promising solution to meet demand for electricity services of rural household in remote locations in developing countries [1]. Typical rural settings in a developing country are characterized by low purchasing power and lack/near lack of grid power. So, this creates an opportunity for PV system to thrive if a medium- or long-term finance scheme is available. According to IFC [2] application of PV power system can be grouped into four main categories; off-grid domestic, off-grid non-domestic, grid connected distributed and grid connected centralized. The paper is focused on off-grid domestic for multiple homes. Insurance is a contract, represented by a policy, in which an individual or entity receives financial protection or reimbursement against losses from an insurance company [3]. Getting an insurance cover entails payment of premium and explicit limitations of the cover/liability. An insurance policy that covers only theft will not pay damages if the insured item is consumed by fire. Insurance premium is usually paid yearly. Atlas Insurance FCC limited has a standard PV policy cover that takes care of: fire, explosion, lightning, earthquake; smoke; storm or flood; riot, civil unrest, strikes, labour \& political distances, malicious persons, escape of water, theft or attempted theft, collision or impact (including by collapsing cranes); breakage or collapse of aerials; falling trees and poles [4]. PV components usually come with manufacturer's warranty but due to volatile nature of the industry, some manufacturers fold up within a short period. So what becomes our faith if there is no insurance and we have premature system failure. Insurance is based on the law of large numbers. The higher the number of objects insured the better. In the Massachusetts, it is mandatory for PV systems of MW scale to have insurance [5]. Typical insurance premiums are between \$0.0075/Watt to $\$ 0.0125 /$ Watt. Malaysian minister of energy, science, technology, environment and climate change; YB Yeo Bee Yin lunched launch the country's first-of-its-kind all risks solar PV insurance policy in 2018. The policy holder will not bear the costs for repairs or replacement of parts, they will also be compensated for loss of income due to downtime arising from damage or theft up to 6 months [6]. This unique insurance is been provided by Allianz Malaysia Bhd. ICCI Lombard of India launched its solar panel warranty insurance that provides cover against performance degradation of solar modules that are under performance warranty [7]. Coverage term is for a minimum of 15 years. In Japan, HDI Global SE currently runs a solar revenue shortfall for owners and investors of PV solar project [8]. Lack of sunshine is one of the biggest risk for owners and investors of PV energy systems in Japan. In order to achieve a high-performance PV plant, the incorporation of automatic data acquisition and monitoring technology is essential [2]. This allows the yield of the plant to be monitored and compared with calculations made from solar irradiation data to raise warnings on a daily basis if there is a shortfall. Faults can then be detected and rectified before they have an appreciable effect on production [2]. Insurance is based on the law of large numbers which states that as the number of identically distributed, randomly generated variables increases, their sample mean (average) approaches their theoretical mean [9]. It can be inferred that as the number of exposure units (policyholders) increases, the probability that the actual loss per exposure unit will equal the expected loss per exposure unit is higher [10].

\section{METHODOLOGY}

This will involve review of related journal articles relevant to the study, collection of data (from name plate and field), selection of electronic hardware/components, modeling, design and simulation of remote monitoring system, testing of the system (Measuring/detection of PV module outputs, inverter load, communicating over web and measuring of individual batteries voltage and finally validation of the results

There are different methods of designing/developing PV system RMS. For the scope of this work, a micro controller and Ethernet controller will be the building block of the RMS. Voltage of each battery will be monitored, inverter load will be taking note of and PV modules power output or 
malfunctioning. The PV system to be monitored is a 48 VDC system that is made up of 4 units of 200Ah battery, 4 units of 250 watts panel and $5 \mathrm{KW}$ inverter.

The hardware comprises of sensors for measurement and communication equipment/device.
Current and voltage of all the panels are monitored. The sensors are modularized and attached to each panel are inverter(s) and battery. Figure-1 shows a block diagram of the study under study.

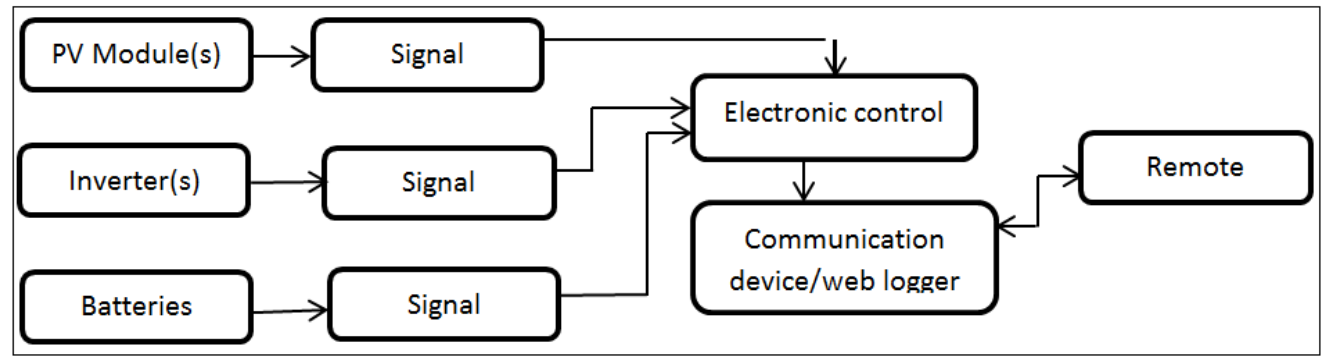

Fig-1: Block Diagram of the System

In Figure-1, sensors are embedded in the corresponding signal processor and take analog input and then convert it to a signal that can be handled by the Electronic Control Unit (ECU). ECU can take 0 to 5VDC. Any signal above 5V DC leads to ECU heat up and eventual burn out. The PV modules are made up of PV cells circuits covered in a laminated seal having ecological resistant, and are the primary building blocks of PV systems. PV module converts light energy to electricity and it is usually rated in watts. The known types of PV cells that are very common are monocrystalline silicon, polycrystalline silicon based on thin film technologies Most PV cells are made of two or more thin layers of semi-conducting material. When light rays fall on this semiconductor, electrical charges are generated and this can be conducted away by metal contacts as Direct Current (DC). In practical terms, PV panels above $200 \mathrm{~W}$ come in $12 \mathrm{~V}$ configuration while the ones below $200 \mathrm{~W}$ are rated within $12 \mathrm{~V}$ range. Panels rated $12 \mathrm{~V}$ can have up to $18 \mathrm{~V}$ open circuit voltage (OCV) while $24 \mathrm{~V}$ configuration has up to $40 \mathrm{~V}$ OCV. Inverters used for this work are electronic machines that convert direct current (DC) to alternating current (AC). It is impossible to use AC machines directly on DC source, which is actually the energy form from the PV modules. The inverter utilizes stored DC charges on the batteries, converts it to AC charges for domestic use. Inverters output can be of different types: sine wave, modified sine wave, and square wave. The sine wave is most commonly used. These inverters also have features of regulating the voltage, current and frequency of the output simultaneously. Inverters are rated in $\mathrm{KW}$ or $\mathrm{KV}$ with corresponding $\mathrm{DC}$ voltage levels. The rated DC voltage tends to increase with increase in inverter capacity (KW/KVA). Batteries used for the study are made up of important parts. These include Anode, cathode and Electrolyte. Batteries stores DC charges which can be used directly with torch flashlights, mobile phones etc. AC devices require and inverter to consume these stored charges. Common types of batteries are lead acid, lithium ion and nickel metal hydride. In the course of this paper, lead acid batteries are used because of its ability to store solar charges and are capable of providing high current and are relatively cheap. Ampere hour (Ah) is the rating of batteries. A 200Ah battery will be able to deliver 200A for one hour theoretically. Batteries are usually connected in a string to achieve inverter DC voltage level. Communication device/Web loggers used in this paper are hardware devices required to transmit data, instructions, and information between sending and receiving devices. Examples of these devices are data modems, cellphones, routers, severs and computers. Wireless communication devices are used in this work. An Electronic Control Unit (ECU) is a device that is in charge of controlling, monitoring, and changing the mode of operation in an electronic system. ECU picks up the $0-5 \mathrm{VDC}$ analog signal and converts it to digital signal that will be passed through communication device to the web. PV Module Signal Processor measures the voltage and current generated by the PV panel since the system will be remotely monitored. This will be importance to monitor the energy generated and output from the PV modules and it is achieved using a programmed microcontroller. V50-ISO Voltage sensor is a high precision voltage sensor that measures from 0 to $\pm 50 \mathrm{~V}$. This sensor gives an output of 0 to $\pm 5 \mathrm{~V}$ depending on the input voltage. It can operate within a temperature range of $-40^{\circ} \mathrm{C}$ to $85^{\circ} \mathrm{C}$. The voltage sensor is based on voltage divider rule as shown in Figure- 2 .

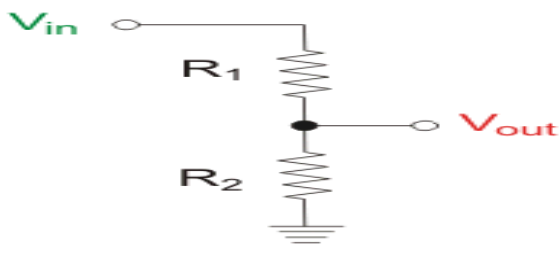

Fig-2: Voltage divider circuit

Vout $=\frac{R 2}{R 1+R 2} * \mathrm{~V}_{\text {in }} \ldots \ldots \ldots \ldots \ldots . . . .1$

Current sensor measures the current produced by the PV panel and give corresponding output. It can 
measure both AC \& DC current. The module comes in $5 \mathrm{~A}, 10 \mathrm{~A}$ and $30 \mathrm{~A}$ configuration. For the purpose of this work, 30A configuration was utilized. Inverter(s) Signal Processor module estimates the load on the inverter and its output AC voltage. Insurance company needs to have idea of the load on the inverter with respect to maximum load capacity. Ideally, inverter should not be loaded beyond $70 \%$ of the rated capacity. Inverter load is measured as drawn current from is which is then converted to KVA by ECU. The load is obtained by load/current drawn with the inverter output voltage. In this module, AC current sensor and AC voltage sensor will be inbuilt in it. AC voltage sensor which is rugged self-powered sensor measures single phase AC voltage ranging from 0 to $300 \mathrm{~V}$, frequency of $48 \mathrm{~Hz}-400 \mathrm{~Hz}$ and gives corresponding output of 0 - 5VDC. Inverter load/AC current sensor (SC100A) is self-powered and gives output of $0-5 \mathrm{VDC}$ while sensing 0 - 100A AC load and works at frequency of $50 / 60 \mathrm{~Hz}$. The closedcircuit voltage $(\mathrm{CCV})$ of each battery is monitored using batteries signal processor voltage sensor. Electronic Control Unit (ECU) receives all analog output from the sensors/signal conditioner and changes to digital signal, multiplexes the data and feed it to dedicated web/server. Corresponding software is used to de-multiplex the signals at the receiver's end.
Microchips, PIC18 (L) F4XK22 microcontroller in the ECU is utilized to achieve this. ECU connects with a router so that it can communicate over internet and for it to be queried remotely. It has 35Input/output (I/O) port. Table-1 shows pin connection of the ECU to monitor four (4) PV panel, one (1) inverter and four (4) batteries.

Table-1: ECU Pin connection to monitor 4 PV panel, one inverter and 4 batteries

\begin{tabular}{|l|l|l|}
\hline Sensor/signal processor & Port & $\begin{array}{l}\text { ECU Pin } \\
\text { Number }\end{array}$ \\
\hline PV voltage sensor 1 & A & 19 \\
\hline PV voltage sensor 2 & A & 20 \\
\hline PV voltage sensor 3 & A & 21 \\
\hline PV voltage sensor 4 & A & 22 \\
\hline Inverter load sensor & B & 9 \\
\hline Inverter voltage sensor & B & 10 \\
\hline Battery 1 processed signal & C & 34 \\
\hline Battery 2 processed signal & C & 35 \\
\hline Battery 3 processed signal & C & 36 \\
\hline Battery 4 processed signal & C & 37 \\
\hline
\end{tabular}

Note: All the sensors/ECU have a common ground for accuracy and optimization

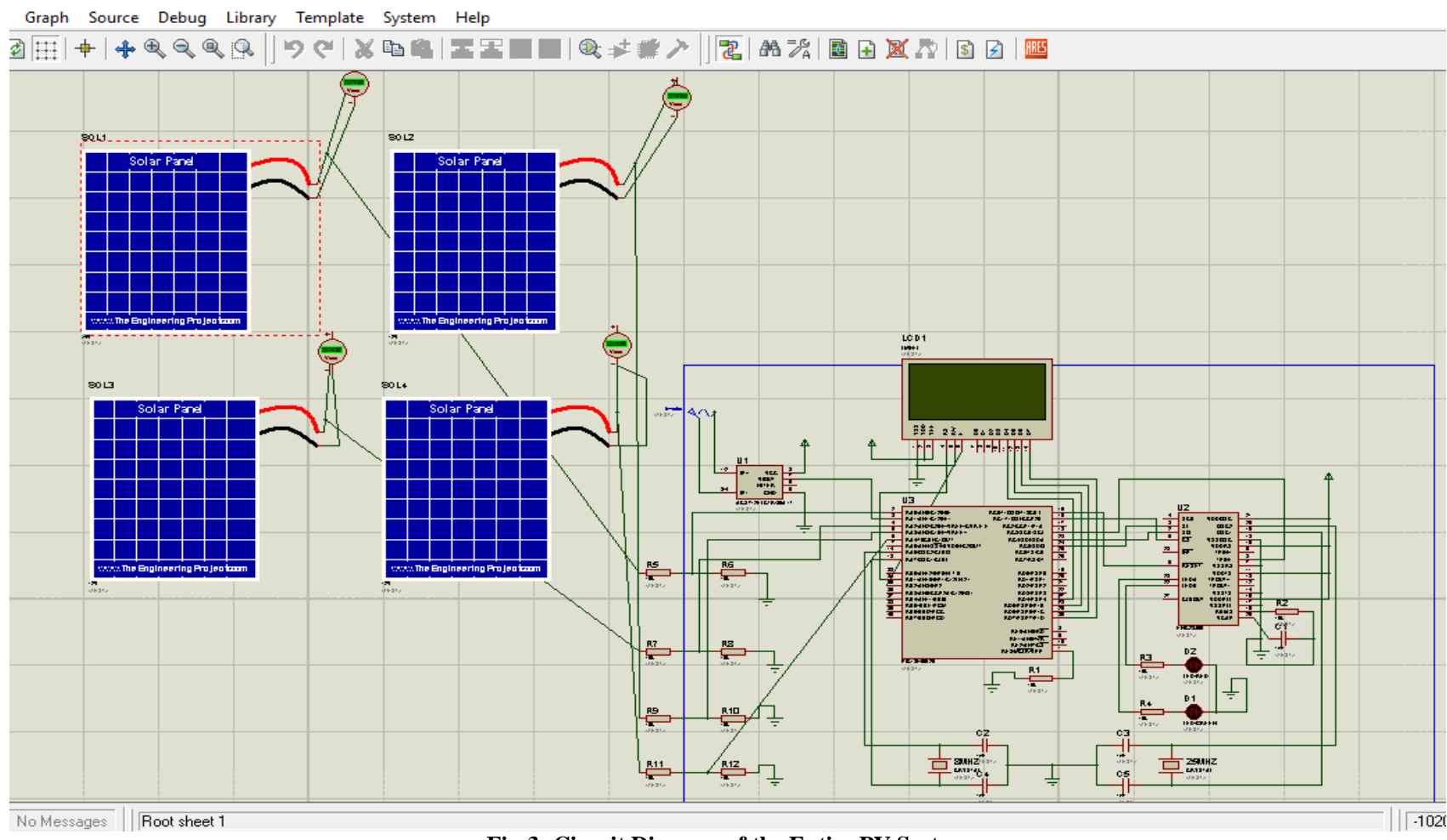

Fig-3: Circuit Diagram of the Entire PV System

\section{TEST, RESULTS AND DISCUSSION}

The test carried out focused on the PV panel power output, $\mathrm{CCV}$ of the batteries and inverter load at start of the day. This is done to confirm connectivity and batteries depth of discharge. It was assumed that morning shift starts by 7:00AM West African Time (WAT). The remote PV system was logged in and initial values captured. The variables were also captured till 9.00AM WAT at 10 minutes interval. The inverter was loaded with constant $5 \mathrm{~A}$ resistive load. 


\begin{tabular}{|l|l|l|l|}
\hline PV 1 (watts) & PV 2 (watts) & PV 3 (watts) & PV 4 (watts) \\
\hline 0 & 0 & 0 & 0 \\
\hline
\end{tabular}

Table-3: Initial CCV of the batteries at 7.00AM WAT

\begin{tabular}{|l|l|l|l|}
\hline Battery 1 (volt) & Battery 2 (volt) & Battery 3 (volt) & Battery 4 (volt) \\
\hline 12.24 & 12.22 & 12.25 & 12.22 \\
\hline
\end{tabular}

\section{PV panel malfunction detection test}

At 2.00PM WAT, a PV malfunction detection test was set up. PV 1 was partially covered/shaded (50\%) with black tarpaulin while PV3 was fully covered with same material. The test was run for 1 hour and values captured remotely at 10 minutes interval.

\section{PV Theft Detection Test}

In order to forestall unnecessary losses, PV theft should be detected in real time. To verify this feature, a PV theft detection test was set up. PV 2 and
PV4 were open circuited. The test was run for 1 hour and values captured remotely at 10 minutes interval.

\section{Inverter Load Test}

The monitoring system is meant to detect level of load on the inverter and send out warning signal when the load is getting above $75 \%$ of its rated capacity. Load was varied remotely by turning strings of incandescent bulb up to and beyond $75 \%$ of the inverter's capacity. Duration of test was 120 seconds. A short duration was used so as to understand how the inverter will behave under real operating stress.

\section{Result from the connectivity and PV power test for 120 minutes}

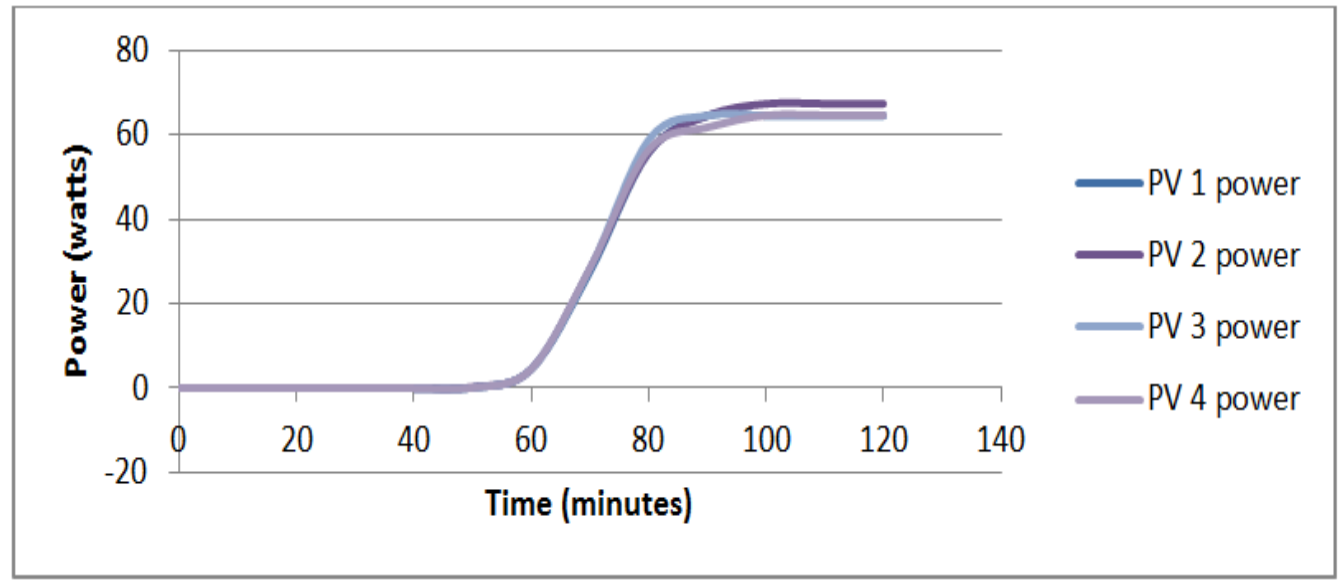

Fig-4: Graph of PV power from 7:00AM - 9:00AM WAT

From figure-4, though there was presence of voltage at 7.00AM WAT, the voltage started translating to power at 8.00AM. The power graph can be divided into three stages of; $0-50$ minutes, $50-75$ minutes, 75 to 120 minutes. From time $0(7: 00 \mathrm{AM})$ to time 50 (7:50AM) power output for the PV panels was zero. Power output of PV1, PV2, PV3 and PV 4 increased from 0 watt to 60 watts at time; $50^{\text {th }}-75^{\text {th }}$ minute. The power reached its peak of 65 watts after $75^{\text {th }}$ minute and remained so throughout the run time. Table-4 shows data log readings of components (PVs1, 2, 3, 4, Batteries and inverter load) used for the study. Time duration was from 7:00am-9:00am for over six months. For presentation purpose one month record is shown here as recorded in Table- 4 . 
Omorogiuwa Eseosa \& Dike Ifeanyichukwu Chukwudi., Saudi J Eng Technol, Feb. 2020; 5(2): 30-37

Table-4: Data log of the components from 7:00AM - 9.00AM WAT

\begin{tabular}{|l|l|l|l|l|l|l|l|l|l|l|l|l|l|l|}
\hline Time & $\begin{array}{l}\text { PV 1 } \\
\text { voltage }\end{array}$ & $\begin{array}{l}\text { PV } \\
\text { current }\end{array}$ & $\begin{array}{l}\text { PV } \\
\text { voltage }\end{array}$ & $\begin{array}{l}\text { PV } \\
\text { current }\end{array}$ & $\begin{array}{l}\text { PV } \\
\text { voltage }\end{array}$ & $\begin{array}{l}\text { PV } \\
\text { current }\end{array}$ & $\begin{array}{l}\text { PV } \\
\text { voltage }\end{array}$ & $\begin{array}{l}\text { PV } \\
\text { current }\end{array}$ & Battery \\
1 CCV & $\begin{array}{l}\text { Battery } \\
\text { 2 CCV }\end{array}$ & $\begin{array}{l}\text { Battery } \\
\text { 3 CCV }\end{array}$ & $\begin{array}{l}\text { Battery } \\
\text { 4 CCV }\end{array}$ & $\begin{array}{l}\text { inverter } \\
\text { load }\end{array}$ \\
\hline $\begin{array}{l}7: 00- \\
30102019\end{array}$ & 6 & 0 & 6.02 & 0.01 & 5.99 & 0 & 6.01 & 0 & 12.24 & 12.22 & 12.25 & 12.22 & 5 \\
\hline $\begin{array}{l}7: 10- \\
30102019\end{array}$ & 6 & 0 & 6.02 & 0.01 & 5.99 & 0 & 6.01 & 0 & 12.24 & 12.22 & 12.25 & 12.22 & 5 \\
\hline $\begin{array}{l}7: 20- \\
30102019\end{array}$ & 6 & 0 & 6.02 & 0.01 & 5.98 & 0 & 6.02 & 0 & 12.23 & 12.22 & 12.23 & 12.21 & 5 \\
\hline $\begin{array}{l}7: 30- \\
30102019\end{array}$ & 9.12 & 0 & 9.09 & 0 & 9.09 & 0 & 9.13 & 0 & 12.22 & 12.2 & 12.2 & 12.19 & 5 \\
\hline $\begin{array}{l}7: 40- \\
30102019\end{array}$ & 9.98 & 0 & 10.2 & 0 & 10 & 0 & 9.97 & 0 & 12.21 & 12.15 & 12.14 & 12.18 & 5 \\
\hline $\begin{array}{l}7: 50- \\
30102019\end{array}$ & 12.2 & 0.01 & 12.18 & 0.02 & 12.21 & 0.01 & 12.22 & 0.009 & 12.2 & 12.15 & 12.14 & 12.17 & 5 \\
\hline $\begin{array}{l}8: 00- \\
30102019\end{array}$ & 18.08 & 0.25 & 18.08 & 0.25 & 18.09 & 0.255 & 18.08 & 0.255 & 12.18 & 12.14 & 12.13 & 12.16 & 5 \\
\hline $\begin{array}{l}8: 10- \\
30102019\end{array}$ & 23 & 1.2 & 23.5 & 1.21 & 23.5 & 1.21 & 23.4 & 1.22 & 12.18 & 12.14 & 12.13 & 12.16 & 5 \\
\hline $\begin{array}{l}8: 20- \\
30102019\end{array}$ & 26.6 & 2.1 & 26.6 & 2.1 & 26.8 & 2.2 & 26.9 & 2.1 & 12.58 & 12.54 & 12.53 & 12.56 & 5 \\
\hline $\begin{array}{l}8: 30- \\
30102019\end{array}$ & 28.05 & 2.3 & 28.07 & 2.3 & 28.08 & 2.3 & 28.09 & 2.2 & 13.12 & 13.16 & 13.14 & 13.18 & 5 \\
\hline $\begin{array}{l}8: 40- \\
30102019\end{array}$ & 28.05 & 2.3 & 28.07 & 2.4 & 28.08 & 2.3 & 28.09 & 2.3 & 13.12 & 13.16 & 13.14 & 13.18 & 5 \\
\hline $\begin{array}{l}8: 50- \\
30102019\end{array}$ & 28.06 & 2.3 & 28.06 & 2.4 & 28.09 & 2.3 & 28.11 & 2.3 & 13.12 & 13.16 & 13.14 & 13.18 & 5 \\
\hline $\begin{array}{l}9.00- \\
30102019\end{array}$ & 28.06 & 2.3 & 28.06 & 2.4 & 28.09 & 2.3 & 28.11 & 2.3 & 13.12 & 13.16 & 13.14 & 13.18 & 5 \\
\hline
\end{tabular}

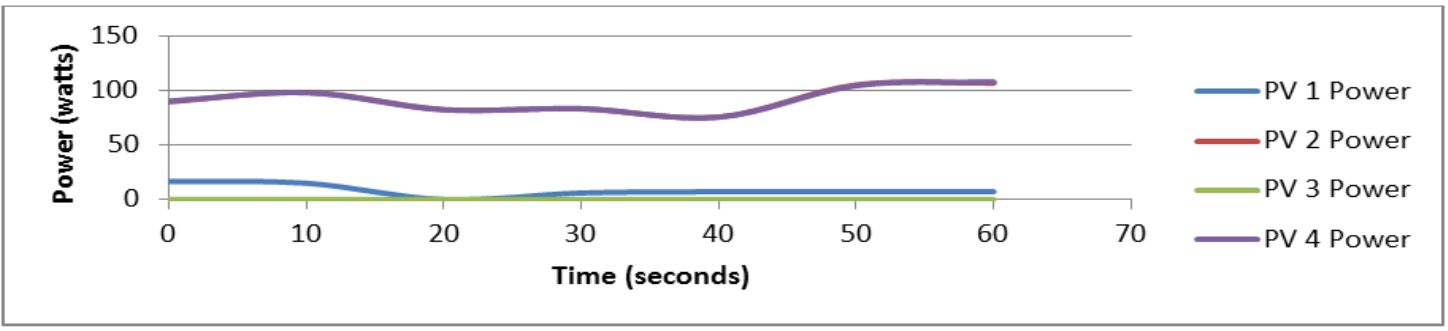

Fig-5: Graph of Power Generated by PV's During Malfunction Test

The smart remote monitoring system was devised to be able to detect a malfunctioning PV panel. Ideally, power generation of PV panels are sinusoidal in nature. From Figure-5, the power graph of PV 2 and PV
4 were identical and oscillating between 75 watts to 110 watts from 0 minute to $60^{\text {th }}$ minute, while that of PV 3 was 0 watts throughout the run time. PV 1 gave low power output hovering between 0 to 18 watts.

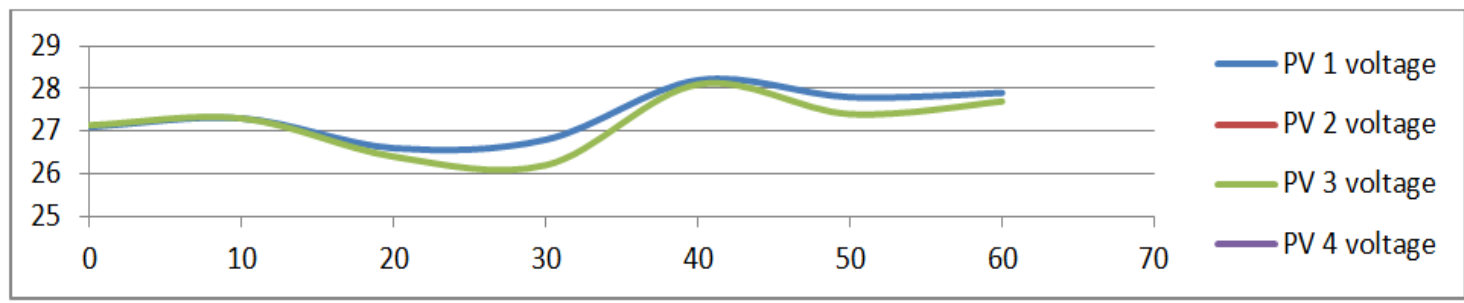

Fig-6: Graph of PV panel's voltages during theft detection test

From figure-6, PV 2 and PV 4 are not visible on the monitoring system. PV 1 and PV3 were up and running. A PV panel that has not been removed from the system is permanently visible on the monitoring system regardless of day or night. 


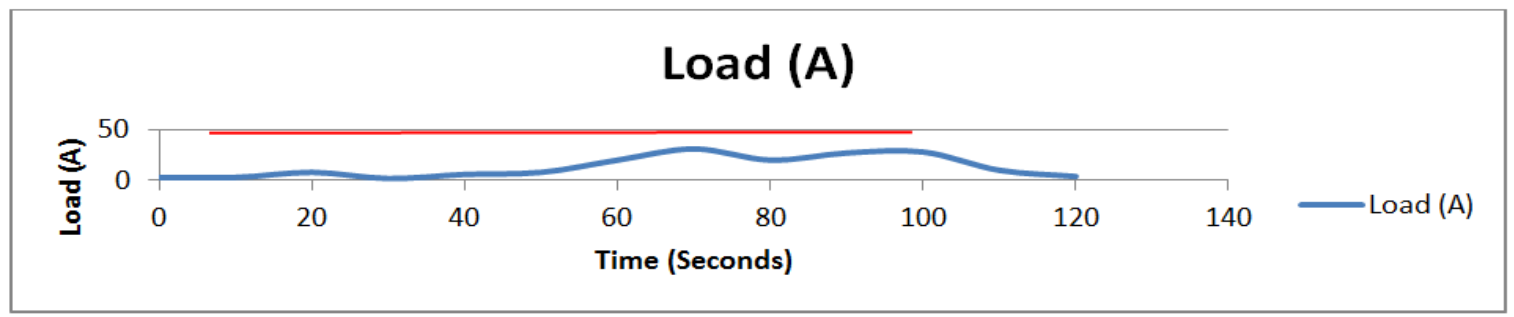

Fig-7: Graph of power drawn during inverter load test

From Figure-7, the red line indicates $75 \%$ of the inverter rating. The inverter under reference is rated 6.5KVA. Load levels above the red line indicates that the inverter is been loaded above recommended level. This happened from $60^{\text {th }}$ second to $75^{\text {th }}$ second, and 80 to $100^{\text {th }}$ second. Inverter load graph also gives us an idea of how the battery is been discharged. A system for remote monitoring of PV system under comprehensive insurance offers a unique and reliable means for insurance providers to have real time access to data and operating dynamics of the insured PV system. In the remote monitoring system (RMS), sensors were installed at the remote/PV system location to capture yield of each PV panel, theft/vandalization of the PV panels, abnormal performance of the PV panels, and inverter load; especially for loads exceeding $75 \%$ of its rated capacity. Insurance provider gets prioritized message for any breach of the inverters' operational procedure and the duration. Analog outputs from the sensors are conditioned and sent into the ECU which converts them to digital signal. The analog sensor signals are conditioned to avoid heating up and burning out of the ECU. ECUS multiplex the data and send them over the internet through a remote router. The multiplexed data is de-multiplexed at the insurers end and each data/value enters the correct data cell. The four PV panels for the test were pinged/queried remotely at 7:00AM WAT, they returned zero power level though there is presence of voltage. This show that current (I) generated is the key determinant of how sustainable a PV system will be. In an area with low visibility, PV panels produce more of voltage; that is high voltage and very low current. To counter this effect, maximum power point tracking (MPPT) charge controller is the in thing in commercial solar deployment. During PV panel power generation and connectivity test for 120 minutes, power output rises sharply as the sky gets clearer reaching a plateau at $75^{\text {th }}$ minute. The maximum recorded power was 65 watts. The variation in power yield of each PV panels was very small and hence negligible. Anytime the variation in power yield starts getting high, then there is a problem coming up. The remote monitoring system detects a malfunctioning PV panel(s) by monitoring and comparing the wave form of PV power generation graphs. From figure-5, the power graph of PV 2 and PV 4 were identical and oscillating between 75 watts to 110 watts from 0 minute to $60^{\text {th }}$ minute, while that of PV 3 was 0 watts throughout the run time. PV 1 gave a low power output hovering between 0 to18 watts. A low power output compared to other identical panel suggests that either PV panel cells are getting or shaded. The shading could be dust, graph or shadows etc. A single shaded or weak PV panel can reduce the yield of the entire PV system drastically. It is not advisable to combine PV panels from different manufacturers during solar installation. Ideally, all the panels for a project should be the same batch. An installed panel with a close circuit must return a voltage level when queried; the value could be zero or any other real value. From figure-6, PV 2 and PV 4 are not visible on the monitoring system. PV 1 and PV3 were up and running. A PV panel that has not been removed from the system is permanently visible on the monitoring system regardless of day or night. If an installed panel is not returning a voltage when queried/pinged, it implies that there is an attempted theft, theft or external tampering of the particular PV panel.

\section{CONCLUSION}

The paper is on developing Remote System for Monitoring PV System. The model was designed and simulated using Proteus Design Suite and Google chrome web browser. Current sensors, voltage sensors/voltage divider network were used to get analog outputs/variables from the PV system. The PV system comprises 4 units of 250 watts polycrystalline panels, one $48 \mathrm{~V} 4 \mathrm{KW}$ inverter and 4 units of 200Ah gel battery. The insurer has interest in these parameters; power yield of each panel, inverter load, batteries depth of discharge and general abuse. PIC18F45K20 which serves as an ECU receives the signals/data and processes them to digital signal. ECU was connected to internet through Ethernet controller (ENC28J60). This ethernet controller has a fast speed and capacity to retransmit undelivered data/packet during collision. A router serves as an access gateway of the Ethernet controller to the internet/web. With this system set up, the insurer can have a bird eyes view of the issues affecting the PV system, and validity/non validity of insurance claim (s). This ensures that the insurer/insurance company does not lose money by paying for damages/insurance claims if end users action leads to break down or malfunctioning of the PV system. The insurer can also call end user or operator to order once system is abused. Moreso, During connectivity test, as shown on Figure-4 PV voltage started translating to power at 8.00AM. Power graph had three periods of $0-50$ minutes, $50-75$ minutes, 75 to 120 minutes. In the first period, power output was 
zero, for second period, power output increased 0 to 60 watts while that of period reached a plateau of 65 watts and remained so throughout run time. For similar panels operating under the same condition, their power output should be uniform. Also, voltage produced by PV panels does not necessarily translate to power at all time. The data logging was fast and reliable. A single malfunctioning PV panel can adversely affect the whole PV system. The monitoring system with its' intelligent algorithm was able to detect that a PV is malfunctioning. Power generations of PV panels are usually sinusoidal. It will be rare to see a PV panel yielding 200Watts drop to 0 zero within a second during the day. In figure-5, PV2 and PV4 power output was oscillating within $75-110$ watts while PV 3 was zero. PV 1 gave a low power output between $0-18$ watts. From the foregoing, it shows that PV 1 is having a partial failure while PV 3 is having total failure. Recall, PV 3 was fully shaded while PV 1 was partially shaded. Theft is a serious issue affecting PV system deployment in remote locations across developing world. Investors/financier are not sure of having the PV panels run throughout its useful life. In the preceding years, some telecom tower operators in Nigeria installed PV panels in their cell sites. In figure-6, there is no visibility of PV 2 and PV 4 on the monitoring system indicating that there is an attempted theft or ongoing theft. PV 1 and PV 3 were still visible. Under normal circumstances, all PV panels are visible on the monitoring system unless someone tampers with it. From Figure-7, any power drawn from inverter that goes above the red line indicates that load is above $75 \%$ of inverter rating. The inverter was loaded above recommended level between $60-75^{\text {th }}$ second and $80-$ $100^{\text {th }}$ second. Loading an inverter beyond $75 \%$ of its rating leads to faster saturation and inverter failure.

\section{ACKNOWLEDGEMENT}

The authors would like to acknowledge the management and staff of eseogietec engineering company limited (www.eseogietec.com) for all their support academically, materially and financially towards the completion of this task. Their facilities were indeed very useful for this task and the researchers would like to recommend them to other fellow researchers.

\section{REFERENCES}

1. Nieuwenhout. (2000). Monitoring and Evaluation of Solar Home Systems. Retrieved from https://energypedia.info/images/0/05/Monitoring_a nd_Evaluation_of_Solar_Home_Systems_in_Deve loping_Countries.pdf

2. IFC. (2011) Utility Scale Power Plants, A Guide for Developers and Investors. Retrieved from http://documents.worldbank.org/curated/en/86803 1468161086726/pdf/667620WP00PUBL005B0SO LAR0GUIDE0BOOK.pdf

3. Julia, K. (2019). Insurance, Investopedia. Retrieved from https://www.investopedia.com/terms/i/insura nce.asp

4. Atlas. (2016). Atlas PV Panels Proposal Form. Retrieved from https://www.atlas.com.mt/wpcontent/uploads/2016/02/pv-panels-proposalform.pdf

5. Patrick, D., Murray, T., \& Sullivan, R. (2016). The Guide to Developing Solar Photovoltaics at Massachusetts Landfills. Retrieved from https://www.mass.gov/files/documents/2016/08/w z/pvlandfillguide.pdf

6. Focus Malaysia. (2018). SEDA: Insurance for Home and Commercial Solar PV. Retrieved from https://www.focusmalaysia.my/All/sedainsurance-for-home-commercial-solar-pv

7. ICICI Lombard. (2017). Solar Panel Warranty Insurance Launched by ICICI Lombard. Retrieved from https://www.icicilombard.com/insuranceinformation/home-insurance-info/article/solarpanel-warranty-insurance-launched-by-icicilombard

8. HDI Japan. (2017). Industrial Insurer HDI Offers Innovative Solar Revenue Shortfall Insurance for Photovoltaic Solar Projects. Retrieved from https://www.hdi.global/downloads/JP_en/2017052 5_NR_HDI-Japan_Solar-Revenue-

Shortfall_Insurance.pdf

9. Routledge. (2016). Law of Large Numbers. Retrieved from https://www.britannica.com/science/law-of-largenumbers

10. Ross, S. (2019). The Law of Large Numbers in the Insurance Industry. Retrieved from https://www.investopedia.com/articles/personalfinance/081616/behind-law-large-numbersinsurance-industry.asp. 